\title{
Satisfaction with interpersonal relations among employees of State Forests in Poland
}

\author{
Stanisław Lachowski ${ }^{1, A-F}$, Magdalena Florek-Łuszczki ${ }^{2, A-F}$, Jerzy Zagórski ${ }^{3, A-F}$, \\ Bogusława Lachowska ${ }^{4, A-F}$ \\ ${ }^{1}$ Maria Curie-Skłodowska University, Lublin, Poland \\ ${ }^{2}$ Institute of Rural Health, Lublin, Poland \\ ${ }^{3}$ Pope John Paul II State School of Higher Education, Biała Podlaska, Poland \\ ${ }^{4}$ John Paul II Catholic University, Lublin, Poland \\ A - Research concept and design, B - Collection and/or assembly of data, C - Data analysis and interpretation, \\ $D$ - Writing the article, E - Critical revision of the article, F - Final approval of article
}

Lachowski S, Florek-Łuszczki M, Zagórski J, Lachowska B. Satisfaction with interpersonal relations among employees of State Forests in Poland. Ann Agric Environ Med. 2018; 25(2): 300-306. doi: 10.26444/aaem/82539

\section{Abstract}

Introduction and objective. The aim of this study is to assess the interpersonal relations of employees of State Forests in Poland, as well as to indicate the factors related to the level of satisfaction with the relations among people employed in similar positions, and relations with superiors.

Materials and method. The issues investigated were developed based on research conducted between 2014-2015 among employees of State Forests in Poland. In each of the 9 forest districts selected, 25 people were selected for testing from 3 groups of employees: foresters, deputy foresters and supervisors, together with administrative staff. Altogether, 399 people took part in the study conducted by means of a questionnaire.

Results. The study showed that the overall level of satisfaction with interpersonal relations among employees of State Forests in Poland is high. Analysis indicated that the demographic characteristics of respondents, such as age, gender or place of residence, had no significant influence on satisfaction with interpersonal relations in the workplace. However, the level of satisfaction with interpersonal relations was positively affected by a high level of overall job satisfaction and satisfaction with remuneration. Decrease in the level of satisfaction was influenced by the accumulation of stressful life events and employment in administration.

Conclusions. Satisfaction with interpersonal relationships in the workplace is an important indicator of employee mental health. Studies have shown the need to broaden the scope of research into the variables that determine the character and personality of an employee.

\section{Key words}

job satisfaction, interpersonal relationships, forestry workers, determinants of satisfaction

\section{INTRODUCTION}

Work is closely related to effort, as well as joy, satisfaction from its creative effects, or the possibility to develop spiritual and physical powers [1]. Work, therefore a dual activity which, by its nature and requirements to involve physical and mental capabilities, may be the source of well-being, pride, fulfilment, or alternatively cause apathy, frustration, illness or even death [2]. Satisfaction from work can be regarded as an indicator of wellness, especially mental and social in the workplace, but also as a factor influencing other spheres of human life (somatic health, family situation).

An important element of the overall satisfaction with work are satisfactory interpersonal relations in the workplace, both among people employed in similar positions, but above all, in relations with superiors. Studies conducted in the 1990s showed that the possibility to work with pleasant people is one of the most appreciated features of work [3]. This feature of employment was indicated by about $2 / 3$ of the respondents, both in Poland (67\%) and in the countries of Western Europe (64\%). Only one of the work features - i.e.

Address for correspondence: Magdalena Florek-Łuszczki, Institute of Rural Health Lublin, Poland, ul. Jaczewskiego 2, 20-090 Lublin, Poland e-mail: magdalena.florek@wp.pl

Received: 02.11.2017; accepted: 10.01.2018; first published: 09.03.2018 a good salary - was recognised as important by a higher percentage of respondents. At the same time, it should be noted that one of the most common reasons for resignations from work were inappropriate relations with superiors [4].

The research by O. N. Prince [5] shows that an important factor for employees' job satisfaction is the recognition which an employee experiences which results from good relationships, both with superiors and colleagues. Recognition from the side of the superior is one of the most common factors for job satisfaction, as indicated by the research by $\mathrm{P}$. Ghenghesh in a group of teachers [6]. Interpersonal relations (with supervisors, co-workers) as a factor of satisfaction are also mentioned by teachers in the research by G. Salma and M. A. Sajida [7]. One of the theories concerning the conditioning of motivation and job satisfaction also refers to the social relations in the work environment. This determines the equal and fair treatment of employees [8] as one of the factors influencing motivation to work and satisfaction from its performance. An employee's experience in whether he/she is treated fairly results mainly from the correct relations with her/his superiors, but also from assessment of the relations with colleagues. K. J. Lawson, A. J. Noblet, J. J. Rodwell [9] in their studies of the relations between satisfaction and 'organizational justice' pay much attention to this factor of satisfaction. An important dimension of this type of 
justice is interpersonal justice, which manifests itself in the perception of employees who are treated fairly by their superiors and colleagues working on an equal footing. The authors point out that the sense of justice is connected with the state of mental health, which proves that the strategies for health promotion in the workplace should also encompass organizational justice. The impact of interpersonal relations on the mental health of employees is also confirmed by research conducted on a large scale (17,390 men and 2,923 women) in 9 in Japanese factories [10]. As a result, it was found that inappropriate relations in the workplace, the sign of which was interpersonal conflicts, were associated with a higher incidence of depression. The link between interpersonal conflict and depression was significantly higher among men with a higher education who were not manual workers, than among men with a low professional status (manual workers with a low educational level).

Studies have also shown that the quality of interpersonal relations has a significant influence not only on the general level of job satisfaction, but also on the health of working people. Evaluating satisfaction of social relations in the workplace and identifying factors that influence the level of satisfaction can be the basis for actions preventing social conflicts and negative health consequences.

In the presented study, the authors search for the factors related to fulfilment and job satisfaction within the fields of research mental health, of sociology and psychology of work. One of the concepts clarifying the diversity of levels of satisfaction from work refers to the different ways of treating work, and divides people into 2 groups, depending on their attitude to work [13]. For some, work is a way of achieving the means to live and they do not have any other expectations of it, while, for the other group, work is a value in itself. Work-oriented people, for whom work is one of the most important values, derive satisfaction from the sole fact of performing the work, but at the same time they have specific requirements concerning work. Their failure is often a source of frustration and disappointment, which directly affects their functioning in the field of mental and physical health. M. Kohn and C. Scholer [14] believe that job satisfaction is one of the psychological effects of performing work. Workoriented people feel immediate satisfaction in the course of its implementation, in accordance with the principle that satisfaction occurs when a person performs actions of their own choosing. In the instrumental treatment of work, satisfaction occurs only after its execution.

\section{OBJECTIVE}

The aim of this study is to assess the interpersonal relations of employees of the State Forests / National Forest Holding in Poland, as well as indicate the factors related to the level of satisfaction from the relations among the people employed at similar levels, and their relations with superiors. The issues were developed based on analysis of the results of research conducted among employees of the State Forests in Poland. The study was conducted in 9 of the 16 provinces in the country.

\section{MATERIALS AND METHOD}

The research material underlying the presented analysis was collected within a research project funded by the State Forests entitled 'Selected health risks in the employees of State Forests work environment in Poland with special emphasis on occupational diseases' (No. OR-2717-39/11). A questionnaire was used to research the matters connected with the job satisfaction of people employed in the State Forests. The main part of the questionnaire was a work evaluation sheet including assessment of relations with colleagues and superiors, assessment of the work and conditions of its performance, assessment of the organisation of work flow, evaluation of opportunities to develop within the workplace, and remuneration. In addition, the questionnaire included a block of questions concerning assessment of the respondent's life situation and a list of stressful life events (Questionnaire Social Readjustment Rating Scale - SRRS), as well as basic information questions. The study was conducted between 2014-2015 in 16 forest districts located in the areas of 9 provinces (Podlaskie, Pomeranian, KuyavianPomeranian, Warmian and Masurian, Mazovian, Lubusz, Lower Silesian, Silesian and Opole). Selection of the research sample consisted of 2 stages. In the first stage, forest districts in different regions of Poland were selected. The choice was made by the Directors of Regional Directorates of State Forests. The criterion for the selection of a forest district was the assessed risk of exposure of forestry workers to occupational diseases. In the chosen forest districts, 25 people were selected for the study, representing 3 employee groups: foresters, deputy foresters and supervisors, together with administrative staff. The study involved 399 people. 7 service employees were excluded from the above- mentioned groups due to the nature of their work (physical work).

The sample group was dominated by men $(86 \%)$, only $14 \%$ of the respondents were women. The vast majority of respondents were long-time employees who had worked in the State Forests for more than 15 years; half of all respondents had worked in the Holding for more than 25 years. The time of employment of only $1 / 5$ of the respondents did not exceed 15 years. The average duration of employment for the sample was 25.1 years. The average age of the respondents was also high (47.8 years). Almost half of the respondents were aged 50 , and $13.3 \%$ of respondents were aged 60 or older. Every fifth respondent (21.4\%) was not over the age of 40 . The level of education divided the respondents into 2 almost equal groups: those who had completed secondary school (49.5\%) and those with higher education (50.5\%). The respondents were employed in 4 groups of job positions. The largest group were foresters $(37.5 \%)$, a slightly smaller group - deputy foresters $(27.6 \%)$ and administrative staff $(27.6 \%)$, and the smallest group were supervisors (rangers and supervision engineers) $-7.4 \%$. Half of the employees of the State Forests lived in rural areas, a quarter of them lived in cities, and others $(21.4 \%)$ in the forestries in the forest.

\section{RESULTS}

The satisfaction of State Forests employees with interpersonal relations was assessed on 2 levels: horizontal - relating to the relationship with co-workers employed in similar positions, and vertical - concerning relations with their superiors. 
On each level, interpersonal relations were evaluated from 3 aspects:

1) assessment of traits of partner relationship;

2) assessment of specific elements of interactions;

3) overall rating of satisfaction from interactions and with their partners.

Assessment of partner relations and individual elements of interactions was made on a rating scale of $1-4: 1-$ absence of interaction, 2 - rather absent, 3 - rather present, 4 - present.

Assessing their colleagues in similar positions, employees of the State Forests emphasised primarily their positive qualities. In general, they agreed (average ratings, approx. 3.5 on a 4 -level scale) that their colleagues at work were friendly, kind and willing to help. The trait specifying that colleagues were close to one another received slightly fewer high ratings $(\bar{x}=3.09)$ (Fig. 1). Respondents tended to be willing to admit that their colleagues were stubborn $(\bar{x}=2.08)$, and only rarely assigned to them entirely negative traits, such as disagreeing, being quarrelsome or lazy.

In assessing the qualities of their immediate superiors, the employees of the State Forests agreed that the superiors were competent - knew what they are doing $(\bar{x}=3.71$ on a 4 - point scale). A high consistency of opinions was observed with such traits among superiors as: honesty, activity, tactfulness. Respondents tended to agree with the opinion that their superior was trustworthy $(\bar{x}=3.3)$ and allowed employees to influence decisions $(\bar{x}=3.2)$.

Negative qualities of the superiors were indicated twice less often. It should be emphasized that among these characteristics, most respondents emphasized that their superiors did not intercede on behalf of employees $(\bar{x}=1.82)$. Employees of State Forests also recognized that some of their superiors were grumpy, ill-informed, were disliked and rude (Fig. 1).

In general, the relationships of the surveyed people entered into with their colleagues were positively assessed (Fig. 2). The most striking feature of the interactions of the surveyed employees was helping out $(\bar{x}=3.44)$. The following features were also highly ranked: showing kindness, honesty, entering into relations of friendship and showing respect and affection. Conflicts in relations and unhealthy rivalry received rather low ratings $(\bar{x}=1.78$, and $\bar{x}=1.65$, respectively).

Employees of the State Forests in Poland recognised mostly positive approaches by their immediate direct superiors (Fig. 2). The possibility of direct contact with the employee's supervisor was especially appreciated $(\bar{x}=3.68$ on a 4 -point scale). High indications were also given to such superiors' behaviour as: concern for a worker's safety, care for good relations, and understanding of employees' problems. To a lesser extent, the respondents confirmed that the supervisor paid attention to their opinion, or was concerned about the life situation of the employee.

Negative behaviour on the part of superiors occurred on a significantly smaller scale, and mainly concerned excessive demands from the employee, as well as behaviour exhibiting signs of mobbing. Among these behaviours, the employees usually indicated setting unrealistic deadlines by supervisors, or entrusting tasks to inadequately qualified employees (Fig. 2). In addition, it happened that superiors made malicious comments aimed at employees, criticized without reasons or publicly ridiculed them, which is

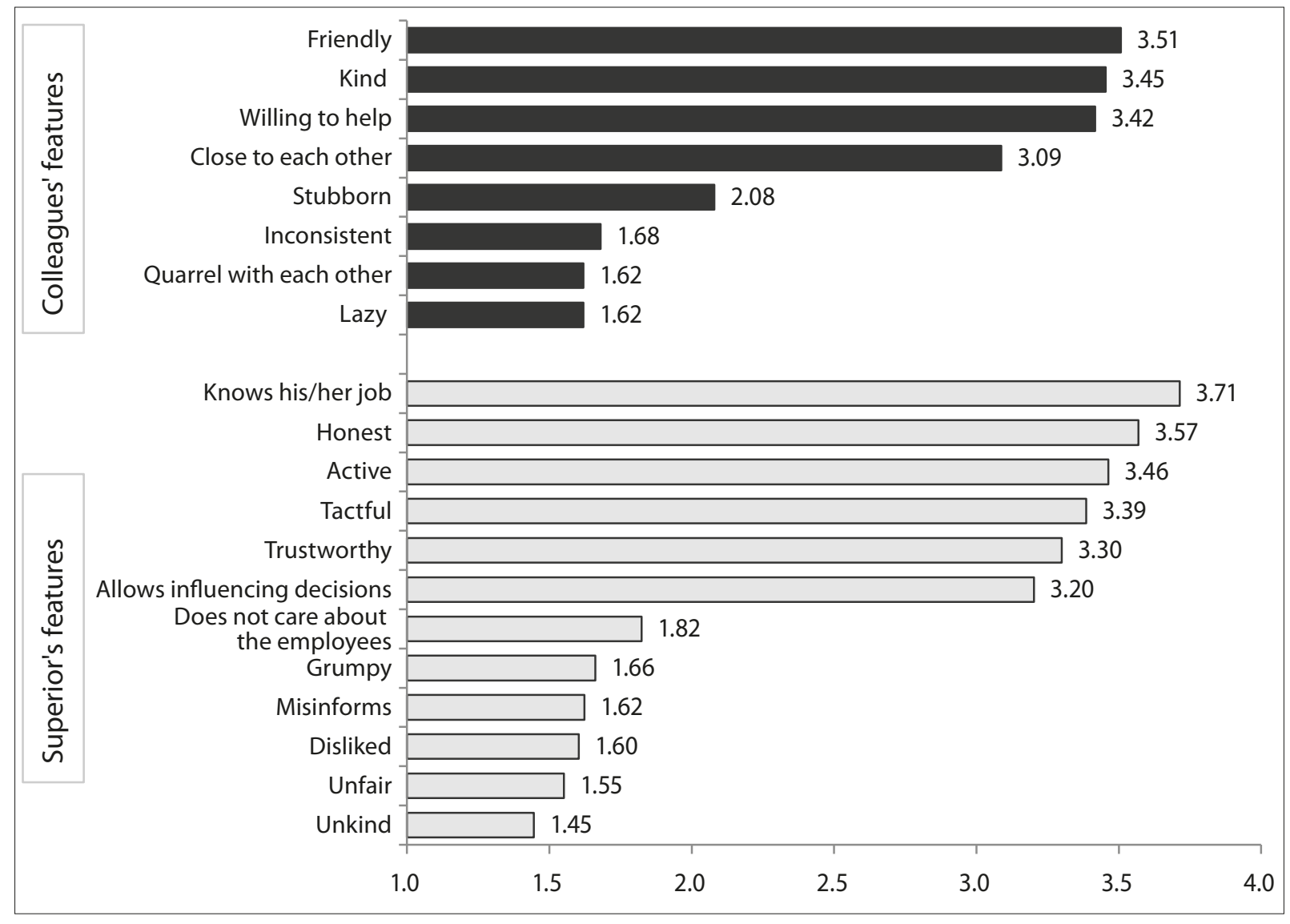

Figure 1. Average indication of superior's features 


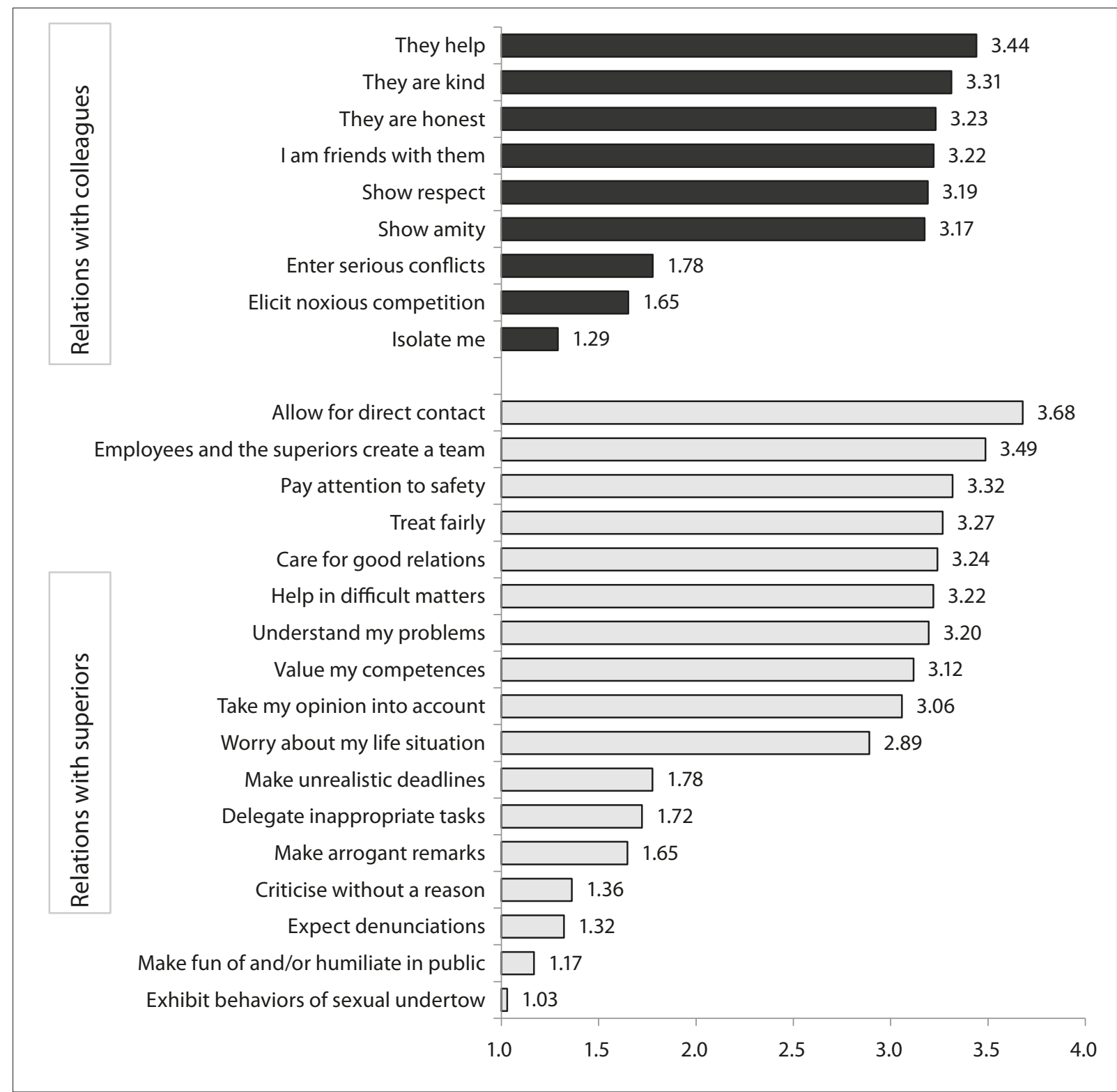

Figure 2. Average assessment of relations with colleagues

undoubtedly culpable behaviour and legally forbidden. Respondents' answers also suggest that there were a few cases where supervisors expected employees to inform against their colleagues, and some behaviours with a sexual undertow.

Each of the dimensions of the assessment of interpersonal relations of forestry employees (evaluation of features of co-workers and a superior, assessment of relations with colleagues and superiors) was reviewed on 7-level satisfaction scale: 1 - great dissatisfaction, 7 - great satisfaction (Tab. 1). The overall level of satisfaction of employees of State Forests in Poland with interpersonal relationships was high. The average satisfaction level for specific dimensions of the relations was close to the value of 6 , which means that the respondents were generally satisfied with the interpersonal relationships. The highest level of respondents' satisfaction occurred in the case of assessment of the relations with coworkers $(\bar{x}=5)$. At the same time, it should be pointed out that the largest percentage of respondents who were very satisfied concerned the assessment of the superior's traits
Table 1. Evaluation of overall satisfaction with co-workers and superiors

\begin{tabular}{|c|c|c|c|c|c|c|c|c|}
\hline \multirow{3}{*}{ Grade } & \multicolumn{8}{|c|}{ Evaluation of satisfaction with: } \\
\hline & \multicolumn{2}{|c|}{$\begin{array}{c}\text { Colleagues' } \\
\text { features }\end{array}$} & \multicolumn{2}{|c|}{$\begin{array}{l}\text { Superiors' } \\
\text { features }\end{array}$} & \multicolumn{2}{|c|}{$\begin{array}{l}\text { Relations } \\
\text { with } \\
\text { colleagues }\end{array}$} & \multicolumn{2}{|c|}{$\begin{array}{l}\text { Relations } \\
\text { with } \\
\text { superiors }\end{array}$} \\
\hline & $\mathrm{N}$ & $\%$ & $\mathrm{~N}$ & $\%$ & $\mathrm{~N}$ & $\%$ & $\mathrm{~N}$ & $\%$ \\
\hline 1. Very dissatisfied & 0 & 0.0 & 3 & 0.8 & 0 & 0.0 & 2 & 0.5 \\
\hline 2. Dissatisfied & 0 & 0.0 & 2 & 0.5 & 1 & 0.3 & 2 & 0.5 \\
\hline 3. Rather dissatisfied & 3 & 0.8 & 13 & 3.3 & 2 & 0.5 & 6 & 1.6 \\
\hline 4. On average satisfied & 37 & 9.4 & 43 & 11.0 & 14 & 3.6 & 26 & 6.7 \\
\hline 5. Rather satisfied & 93 & 23.7 & 63 & 16.1 & 88 & 22.4 & 93 & 24.0 \\
\hline 6. Satisfied & 223 & 56.9 & 192 & 49.1 & 239 & 61.0 & 200 & 51.7 \\
\hline 7. Very satisfied & 36 & 9.2 & 75 & 19.2 & 48 & 12.2 & 58 & 15.0 \\
\hline Generally & 392 & 100.0 & 391 & 100.0 & 392 & 100.0 & 387 & 100.0 \\
\hline Average from grades & 5.64 & & 5.65 & & 5.80 & & 5.68 & \\
\hline
\end{tabular}

* does not include, data not available 
Table 2. Models of assessment of interpersonal relations conditioning (results of multiple regression analysis with stepwise approach)

\begin{tabular}{|c|c|c|c|c|c|c|c|c|}
\hline \multirow{2}{*}{$\begin{array}{l}\text { Indicators of interpersonal relations } \\
\text { (Explained variable) }\end{array}$} & \multirow{2}{*}{ Predictors } & \multicolumn{2}{|c|}{ ANOVA } & \multicolumn{2}{|c|}{ Coefficients B } & \multirow{2}{*}{$\mathrm{t}$} & \multirow{2}{*}{$\mathrm{p}$} & \multirow{2}{*}{$\mathrm{R}^{2}$} \\
\hline & & $\mathrm{F}$ & $\mathrm{p}$ & non-standardized & standardized & & & \\
\hline \multirow{4}{*}{ Assessment co-workers' traits } & (constant) & & & 2.200 & & 13.460 & 0.000 & \multirow{4}{*}{0.193} \\
\hline & Satisfaction with remuneration & 22.372 & 0.000 & 0.097 & 0.206 & 3.371 & 0.001 & \\
\hline & Stress level & & & -0.001 & -0.134 & -2.851 & 0.005 & \\
\hline & Job - Administration & & & -0.113 & -0.112 & -2.411 & 0.016 & \\
\hline \multirow{3}{*}{$\begin{array}{l}\text { Level of satisfaction with relations with } \\
\text { co-workers }\end{array}$} & Job satisfaction & \multirow{3}{*}{11.716} & \multirow{3}{*}{0.000} & 0.060 & 0.205 & 4.129 & 0.000 & \multirow{3}{*}{0.085} \\
\hline & Education & & & -0.059 & -0.129 & -2.568 & 0.011 & \\
\hline & Job - Administration & & & -0.060 & -0.113 & -2.252 & 0.025 & \\
\hline \multirow{4}{*}{ Assessment of superior's traits } & (constant) & \multirow{4}{*}{17.368} & \multirow{4}{*}{0.000} & 2.193 & & 11.870 & 0.000 & \multirow{4}{*}{0.122} \\
\hline & Job satisfaction & & & 0.145 & 0.227 & 3.555 & 0.000 & \\
\hline & Job - deputy forester & & & -0.123 & -0.107 & -2.197 & 0.029 & \\
\hline & Satisfaction with remuneration & & & 0.074 & 0.137 & 2.143 & 0.033 & \\
\hline \multirow{2}{*}{$\begin{array}{l}\text { Level of satisfaction with the relations } \\
\text { with superiors }\end{array}$} & Job satisfaction & \multirow[t]{2}{*}{41.366} & \multirow[t]{2}{*}{0.000} & 0.096 & 0.350 & 6.818 & 0.000 & \multirow[t]{2}{*}{0.180} \\
\hline & Satisfaction with remuneration & & & 0.041 & 0.135 & 2.626 & 0.009 & \\
\hline
\end{tabular}

(19.2\%), and the least - assessment of colleagues' traits (9.2\%). Although $1 / 5$ of respondents were very satisfied with their superior's traits, at the same time, a relatively high proportion (15\% of all respondents) expressed average satisfaction or even dissatisfaction with their superior's traits. Dissatisfaction or average satisfaction occurred on the smallest scale in the assessment of relations with colleagues $-4.4 \%$ of the sample (Tab. 1), and to a much greater extent in the evaluation of traits of co-workers (10.2\%) and in the assessment of relations with superiors $(9.3 \%)$.

The nature of interpersonal relations in the workplace and employees' satisfaction from these relations is undoubtedly one of the factors influencing the overall level of job satisfaction [13]. Satisfaction with interpersonal relations can also be regarded as the attitude towards social relations in the workplace (dependent variable), which is influenced by various factors. It is hypothesized that 4 groups of factors (predictors) affect the assessment of interpersonal relations among employees of the State Forests:

1) socio-demographic characteristics of the respondents (gender, age, education, place of residence);

2) nature of the work (seniority, position);

3) level of job satisfaction (job satisfaction, salary contentment);

4) respondent's life situation (life satisfaction, contentment with the family situation, satisfaction with financial situation, and level of stress due to life events [14].

In order to determine which of these predictors had a significant influence on the assessment of interpersonal relations, multiple linear regression analysis was used with a stepwise approach of predictors input. The analysis was applied to the 4 dependent variables defining interpersonal relations among forestry workers:

1) assessment of co-workers' traits;

2) level of satisfaction with co-workers' traits;

3) assessment of superior's traits;

4) level of satisfaction with superior's traits.

An identical set of 15 independent variables was introduced in each analysis: gender, age, education, work experience, place of residence, employment on forester position, employment on deputy forester position, employment on administrative position, employment on a supervisory position, assessment of satisfaction with salary, job satisfaction, levels of stress due to life events, assessment of life satisfaction, satisfaction with financial situation, and satisfaction with family situation. The iIndependent variables were converted to nominal variables bivalent (dichotomous).

Analysis of regression showed that only a few variables had a significant influence on the indicators of interpersonal relations of the State Forests employees in Poland. The assumption that these relations depend on the demographic characteristics of the respondents (gender, age, place of residence) was not confirmed. Interpersonal relations, family situation or financial situation of the respondents were also not affected. The following had the biggest impact on the interpersonal relations existing among the employees: general satisfaction with the job, job position and traumatic life events. However, it should be noted that the models of specific interpersonal relationship indicators differed slightly (Tab. 2).

Grades which the examined employees attributed to their colleagues' traits remained closely connected with the general level of job satisfaction, salary contentment, levels of stress caused by life events during the previous year, and with their position in the administration (Tab. 2). A positive correlation $(\beta=0.206)$ combined satisfaction with work and remuneration, which means that the more the respondents were satisfied with their work and pay, the better they evaluated their colleagues' traits. High levels of stress due to difficult life events and work in administration, negatively influenced the co-workers' traits $(\beta=-0.134 ; \beta=-0.112$, respectively).

As far as the people working in the forestry were concerned, the level of satisfaction with the relations with co-workers depended on 3 predictors: job satisfaction, position in the administration (these variables were in the model of co-workers traits assessment) and education (Tab. 2). Respondents working in the forestry who were more satisfied with work, were also more satisfied with their relationship with co-workers $(\beta=-0.205)$, while those working in the administration were less satisfied with their co-workers $(\beta=-0.113)$. Satisfaction with these relations was also negatively affected by the level of education: those better educated evaluated as worse their relations with colleagues employed in equivalent positions $(\beta=-0.129)$. 
Interpersonal relations with superiors, were influenced to a great extent primarily by general job satisfaction and satisfaction with salary. These predictors were both in the model of the superior's traits assessment conditioning, and in the model of level of satisfaction with the supervisor's conditioning. In both models, these variables had a positive effect on the interaction with superiors (Tab. 2). In addition, in the model of evaluation of determinants of the superior's traits, there occurred a variable that specified the employment in the position of deputy forester. Working in this position negatively correlated with evaluation of the superior's traits $(\beta=-0.107)$, which means that deputy foresters evaluated their superiors worse than other employees of State Forests.

Although the results of the analysis of variance ( $\mathrm{F}$ and $\mathrm{p}$ in Tab. 2) show that the regression models are well matched to the empirical data, it must be admitted that the predictors of the individual models explain the variability of the dependent variables to a small percentage. The variability in the assessment of colleagues' traits and the level of satisfaction with the relations with superiors is explained in the largest percentage (about 20\%). A very small percentage of differences in satisfaction with the relationship with coworkers $(8.5 \%)$ is explained.

\section{DISCUSSION}

The study shows that the overall level of satisfaction with interpersonal relations of employees of State Forests is high. The majority of respondents were satisfied or very satisfied with their relations with superiors, as well as with people working on an equal footing. The respondents participants were much more likely to indicate the positive traits of their superiors and colleagues than to their negative traits. At the same time, it should be stressed that in assessing the traits of their colleagues and superiors, the employees of State Forests expressed extremely different opinions much more often in respect to supervisors than with respect to their co-workers. $1 / 5$ of respondents expressed the highest level of satisfaction with their superiors, while only about half of them expressed such a level of satisfaction with their colleagues. A low level of satisfaction was also significantly more common in relation to the superiors than to co-workers. Therefore, relations with superiors are characterized by greater variability than relations with co-workers. A relatively large part of respondents (about 1/5) had a very good relationship with superiors; however, at the same time, noticeable differences occurred in a substantial part of the respondents replies.

Many authors $[15,16,17,18]$ draw attention to the fact that work which meets the needs of those performing it is a source of satisfaction. Undoubtedly, general satisfaction with work is proof of the fulfilment of the expectations placed in it, and satisfaction with pay allows fulfilling necessary needs. It therefore seems understandable that those aspects of satisfaction with work positively influence the interpersonal relations among forestry workers. People who are more satisfied with work and their remuneration are also more satisfied with the traits of their co-workers and superiors, and their mutual interaction. The tendency to negatively assess their colleagues is typical of a person with a high level of stress due to difficult life events. The established relations are consistent with the overall regularity that a traumatic situation has a negative impact on the functioning of a human being, particularly in the mental $[19,20]$ or even somatic [21] spheres. As a result of those events, the most common instances of negative emotions occur, which may influence relations with the environment. Studies by Ogińska-Bulik [22] indicate that the impact is not necessarily negative. The author proved that among people who have experienced traumatic life events, there was a relatively high level of positive changes in relations with other people. However, it should be noted that the author focused on positive changes exclusively, disregarding negative changes.

The presented analysis indicates that the demographic characteristics of the studied employees of State Forests, such as: age, gender or place of residence, did not have a significant influence on the satisfaction with interpersonal relations in the workplace. Springer [23] obtained similar results while examining satisfaction with work among the residents of the district of Poznań in Poland. The author concluded that the demographic characteristics of people of working age have no significant effect on the satisfaction of employees. Variables determining the social status expressed by a job position had a significant influence on satisfaction. Research by J. F. Terelaka and P. Jankowska [24] also indicated the job position as a factor of satisfaction with work. The research also indicated that a complementary fit is a predictor of satisfaction with work, depending on the position. In the presented study, the characteristics of professional status were also the predictors of satisfaction with social relations of employees of State Forests. Negative assessments of the interpersonal relations of the polled employees of State Forests are indeed related to the level of education and job position. Respondents with a higher level of education and working in the administration were less satisfied with their co-workers, while those working as foresters evaluated the traits of their colleagues working on an equal footing, as being worse.

\section{CONCLUSIONS}

The results of the analysis indicate that satisfaction with social relations in the workplace, to a large extent depends on the overall satisfaction with work, including satisfactory salaries. Reduction in the level of satisfaction was affected by the accumulation of stressful life events. Because many authors note that important predictors of job satisfaction and interpersonal relations connected with it are employees' character traits and personality, it seems advisable to broaden the research into the psychological factors of satisfaction from social relations in the workplace.

\section{REFERENCES}

1. Strzeszewski Cz. Praca ludzka zagadnienia społeczno-moralne. Wydanie internetowe na podstawie wydania Towarzystwa Naukowego Katolickiego Uniwersytetu Lubelskiego, Lublin 1978 opracował: Tomasz Wójcik Wrocław 2004; http://mopl.pwr.wroc.pl/kul/Praca\%20 Ludzka.pdf

2. Bańka A. Jaskość życia w psychologicznych koncepcjach człowieka i pracy. W: Psychologiczne i pedagogiczne wymiary jakości życia. Red. A Bańka, R Derbis, Środkowoeuropejskie Centrum Ekonomii Działania Społecznego, Poznań-Częstochowa 1994; 19-40.

3. Nowicka M. Społeczeństwo konkurencyjne? Postawy wobec pracy w Polsce i państwach Unii Europejskiej. Studia Europejskie 1999; 4: 51-73. 
4. Szałach S. Zaufanie w relacjach interpersonalnych wybrane aspekty. Edukacja Humanistyczna 2013; 1 (28): 177-183.

5. Prince ON. Teachers Job Satisfaction and Motivation for School Effectiveness: An As sessment. Reports - Evaluative. University of Helsinki Finland. Helsinki 2006.

6. Ghenghesh P. Job Satisfaction and Motivation - What Makes. Teachers Tick? Br J Educ Soc Behav Sci. 2013; 3(4): 456-466.

7. Salma G, Sajid MA. Teacher's Motivation \& Job Satisfaction. Int J Manag Sci Busi Res. 2012; 1: 56-66.

8. Lawson KJ, Noblet AJ, Rodwell JJ. Promoting employee wellbeing: the relevance of work characteristics and organizational justice. Health Promot Int. 2009; Sep; 24(3): 223-33.

9. Inoue A, Kawakami N. Japan Work Stress and Health Cohort Study Group. Interpersonal conflict and depression among Japanese workers with high or low socioeconomic status: findings from the Japan Work Stress and Health Cohort Study. Soc Sci Med. 2010; Jul; 71(1): 173-80.

10. Sarapata A (ed.). O zadowoleniu i niezadowoleniu z pracy. CRZZ, Warszawa 1977.

11. Kurek D. Relacje interpersonalne a satysfakcja z pracy pracowników naukowo-dydaktycznych akademii obrony narodowej. Zeszyty Naukowe AON 2014; 2(95): 295-296.

12. Ratajczak Z. Elementy psychologii pracy. UŚ, Katowice 1991.

13. Siekanska M, Sekowski A. Job satisfaction and temperament structure of gifted people. High Ability Stud. 2006; 17(1): 75-85.
14. Kohn M, Scholer C. Praca a osobowość - studium współzależności. PWN. Warszawa 1996.

15. Robbins SP. Organizational behavior. Concepts controversies and applications. Prentice-Hall: International Editions 1991.

16. Chusmir LH, Parker B. Success Strivings and Their Relationship to Affective Work Behaviors: Gender Differences. J Soc Psychol. 1992; 132(1): 87-99.

17. Borys B. Sytuacje ekstremalne i ich wpływ na stan psychiczny człowieka. Psychiatria 2004; 1: 97-105.

18. Dąbrowska M. Wpływ traumatycznych doświadczeń na zdrowie psychiczne dzieci i młodzieży. Psychiatria w Praktyce Ogólnolekarskiej 2006; 6 (4): 161-164.

19. Aazami S, Shamsuddin K, Akmal S, Azami G. The Relationship Between Job Satisfaction and Psychological/Physical Health among Malaysian Working Women. Malays J Med Sci. Jul-Aug 2015; 22(4): 40-46.

20. Saari LM, Judge TA. Employee Attitudes and Job Satisfaction. Hum Resource Management. 2004; 43 (4): 395-407.

21. Ogińska-Bulik N. Potraumatyczny wzrost - zróżnicowanie ze względu na rodzaj doświadczonego zdarzenia oraz płeć i wiek badanych osób. Acta Universitatis Lodziensis Folia Psychologica 2013; 17: 51-66.

22. Springer A. Wybrane czynniki kształtujące satysfakcję pracownika. Problemy Zarządzania 2011; 9, 4 (34): 162 - 180.

23. Terelak JF, Jankowska P. Dopasowanie jednostka - organizacja a zadowolenie z pracy. Studia i Materiały. Miscellanea Oeconomicae 2009; 1: 229-254. 